\title{
Recenzja książki Stowo, obraz, dźwięk w mszach świętych z udziałem dzieci pod red. Henryka Sławińskiego i Wiesława Przyczyny, Redemptoris Missio XXXIV, Wydawnictwo Naukowe Uniwersytetu Papieskiego Jana Pawła II w Krakowie, Kraków 2019, ss. 232
}

Posługiwanie się dziś w liturgii, w przepowiadaniu, a zwłaszcza w homiliach do dzieci, różnego rodzaju pomocami audiowizualnymi stało się czymś w rodzaju niepodważalnej prawdy. Wielu kaznodziejom wydaje się, że bez multimediów przekaz kazań będzie nie tylko mało interesujący, ale również nieskuteczny. Dlaczego księża „chowają” się za rekwizyty? Dlaczego nie wystarczają im słowa i gesty jako podstawowe środki przekazu zbawczego orędzia?

$\mathrm{Na}$ te i podobne pytania stara się odpowiedzieć wyczerpująco publikacja przygotowana przez Wydawnictwo Naukowe Uniwersytetu Papieskiego Jana Pawła II w Krakowie, pod redakcją dwóch znanych teologów z Katedry Komunikacji Religijnej na Wydziale Teologicznym tejże uczelni: ks. Henryka Sławińskiego i ks. Wiesława Przyczyny, pt. Słowo, obraz, dźwięk w mszach świętych $z$ udziatem dzieci. Książka jest wieloautorską monografią naukową. Składa się ze wstępu redaktorów, jedenastu prac różnych autorów w dwóch działach tematycznych oraz debaty będącej zapisem najciekawszych fragmentów dwóch dyskusji, które odbyły się w Krzeszowicach w 2008 i Krakowie w 2009 roku. Publikacja stanowi studium interdyscyplinarne. Jej celem jest wielowymiarowe spojrzenie na zagadnienie podane w tytule. Autorzy poszczególnych tekstów analizują je z punktu widzenia uprawianej przez siebie nauki.

Redaktorzy książki uznali, że czytelnik powinien poznać najpierw współczesny kontekst mszy świętych z udziałem dzieci. Mają mu w tym pomóc dwa teksty. Pierwszy z nich - autorstwa Elżbiety Dryll, prowadzącej badania w nurcie psychologii narracyjnej — podejmuje zagadnienie komunikacji werbalnej w miste- 
rium Kościoła. Tekst zawiera wiele ważnych wypowiedzi na temat środków technicznych w przestrzeni przepowiadania. Autorka uważa m.in., że nie powinny one zasłaniać „osób”, gdyż liturgia i głoszenie słowa Bożego w jej ramach stanowią autentyczne spotkanie, a treści religijne można w pełni wyrazić tylko w kodzie symbolicznym - werbalnym; forma jest ważna, ale nie powinna sobą angażować.

Drugi zaś tekst jest wypowiedzią psychologa języka i komunikologa, ukazującą komunikacyjno-doświadczeniowe konsekwencje korzystania z nowoczesnych technologii multimedialnych w liturgii. W obliczu takich zagrożeń jak multimedializacja liturgii czy desakralizacja przekazu liturgicznego Adam Skibiński wzywa do ostrożności i selektywności w doborze środków multimedialnych, widząc w nich jedynie „narzędzia zbliżenia się do Pana” (s. 39).

Następny dział dotyczy celebracji mszy świętych z udziałem dzieci. Rozpoczyna go artykuł ks. Henryka Sławińskiego, który — jak się wydaje — gra rolę tekstu wiodącego i porządkującego. Msza święta z udziałem dzieci i głoszona do nich homilia zostały tu ukazane w świetle Dyrektorium o mszach z udziałem dzieci z 1973 roku, jak też innych późniejszych dokumentów Kościoła. Autor omawia najpierw to, co w Dyrektorium jest nadal aktualne, a następnie podejmuje kwestię dezaktualizacji niektórych proponowanych w nim adaptacji. Potwierdza aktualność zaleceń w odniesieniu do homilii dialogowanych z elementami wizualizacji podczas mszy z udziałem dzieci. W konkluzji wzywa do wystrzegania się legalizmu, gaszącego duszpasterską kreatywność i przypomina, że homilia na każdej mszy świętej — także i tej z udziałem dzieci — powinna być adresowana do całego wielorako zróżnicowanego zgromadzenia liturgicznego.

Drugi z kolei tekst daje czytelnikowi możliwość spojrzenia oczyma psychologa na mszę świętą z udziałem dzieci. Zdaniem Marii Ligenzy nie powinna ona przyjmować formy zorganizowanej zabawy, co nie wyklucza pewnych zabawowych form wyrażania radości ze spotkania z Bogiem. Przyjście do kościoła nie powinno jednak kojarzyć się dziecku z zabawą, lecz „czymś wzniosłym, a jednocześnie ciekawym, bo tajemniczym" (s. 77).

Trzeci artykuł - napisany przez homiletę, ks. Huberta Łysego - analizuje w sposób dogłębny polską posoborową teorię i praktykę homilii do dzieci i formułuje dziesięć postulatów liturgicznego i pozaliturgicznego przepowiadania do tej grupy słuchaczy. Autor przypomina m.in., że dzieci uczą się wiary zarówno $\mathrm{z}$ tego, co słyszą, jak i z tego, co widzą (fides ex auditu et visu; por. Rz 10,17), oraz to, że homilia do dzieci wymaga bardzo dobrego przygotowania.

Następny na temat homilii do dzieci wypowiada się liturgista, ks. Erwin Mateja. Na podstawie swoich wieloletnich obserwacji doszedł on do wniosku, że duszpasterze dość szeroko traktują słowa z Dyrektorium o tym, iż tematyka homilii do dzieci może być przybliżona przez wykorzystanie obrazów przygotowanych przez dzieci (por. DMD 36), i często posługują się w swoich homiliach przezroczami, rekwizytami, kukiełkami czy nawet żywymi aktorami. Zauważa, 
że kaznodzieje często tak bardzo skupiają się na wzbudzeniu zainteresowania u dzieci, że w gruncie rzeczy głoszą im to, czego one chcą, a nie to, co chce powiedzieć im Bóg.

Aspekty psychologiczne informacyjnej i formacyjnej roli homilii i kazań do dzieci zostały przedstawione w pracy psychologa rozwojowego, Moniki Borowskiej. Szczególnie ważne w obrębie kwestii podjętej w tej książce wydaje się podkreślenie tu potrzeby znajomości przez kaznodziejów podstaw psychologii rozwojowej dziecka, cech jego myślenia - nie po to jednak, by je powielać w przekazie, lecz ażeby je uwzględnić przy antycypowaniu jego subiektywnej perspektywy poznawczej, czyli jego odbioru homilii i kazania, i dopuszczaniu jego aktywności własnej.

Następny tekst umożliwia czytelnikowi spojrzenie na homilię do dzieci okiem pedagoga. Anna Walulik CSFN patrzy na przepowiadanie do dzieci jako na sytuację wychowawczą. Uważa, że homilista, uwzględniając warunki liturgicznego przepowiadania, głosi słowo Boże, ale też tworzy środowisko sprzyjające osobowościowemu i religijnemu rozwojowi dziecka. Odnosząc się zaś do praktyki tzw. „homilii aktywizujących”, twierdzi, że stosowane w nich metody i środki dydaktyczne powinny umożliwiać współdziałanie wychowawcy i wychowanka. Dlatego homilista powinien reprezentować wysoki stopień nie tylko kompetencji teologicznych, ale i dydaktycznych.

Dalej redaktorzy zamieścili bardzo ciekawy artykuł Anety Załazińskiej, ukazujący kazanie do dzieci z perspektywy lingwistyczno-komunikacyjnej. Autorka patrzy na nie jako na dynamiczne zdarzenie komunikacyjne. Jej zdaniem

dobra homilia, tak jak dobra komunikacja, wymaga zaangażowania wszystkich uczestników, użycia właściwych środków językowych i niejęzykowych, a jej skuteczność mierzona jest nie tylko poziomem zrozumienia, ale także emocjonalnego przeżycia, zapamiętania i włączenia do systemu poznawczego wspólnie wytworzonych idei, konceptów czy stanów (s. 150-151).

Dziecko zatem - uważa Autorka — więcej korzysta z homilii z elementami interakcyjno-dialogowymi niż z przemowy w formie czysto monologowej.

Wśród prac odnoszących się do kaznodziejstwa dziecięcego nie mogło zabraknąć wypowiedzi językoznawcy i dydaktyka języka. Artykuł Danuty Krzyżyk i Heleny Synowiec na temat wzorców stylistycznych w homiliach do dzieci omawia strukturę oraz cechy języka i stylu takich homilii, wytykając kaznodziejom liczne błędy składniowe, frazeologiczne i słownikowe w homiliach do dzieci, zakłócające ich komunikatywność. Autorki postulują uwzględnienie lepszego przygotowania językowego w procesie kształcenia przyszłych kaznodziejów.

Ostatni artykuł ukazuje znaczenie języka i pomocy audiowizualnych w homiliach do dzieci. Jego autor, bp Antoni Długosz, znany praktyk kaznodziej- 
stwa dziecięcego, wyraża przekonanie, że w przekazie homiletycznym do dzieci należy zwracać szczególną uwagę na język, który musi być dostosowany do możliwości percepcyjnych dziecka, na jego doświadczenie egzystencjalne oraz wykorzystanie pomocy audiowizualnych, angażujących wszystkie zmysły, oddziałujących wielopłaszczyznowo na młodego słuchacza, jako że sam Bóg działa w historii ludzkości i komunikuje się z nami przez wydarzenia rozgrywające się wokół nas.

Kończący książkę zapis debat, w czasie których znani teolodzy, językoznawcy, psycholodzy, komunikolodzy i medioznawcy zastanawiali się nad stosowaniem werbalnych i niewerbalnych środków wyrazu (słowo i gest), a zwłaszcza nad możliwością użycia nowych technologii (np. obraz elektroniczny) i różnego rodzaju rekwizytów w przepowiadaniu homilijnym - podobnie jak wcześniej zamieszczone artykuły — nie tylko poszerza wiedzę czytelnika, daje mu wgląd w złożoność problematyki, przede wszystkim zaś pokazuje, że zabiegając o uatrakcyjnienie przepowiadania, należy przede wszystkim zatroszczyć się o to, ażeby liturgia wraz ze swoją integralną częścią, którą jest homilia, pozostały sobą.

Głównym przesłaniem tej od dawna oczekiwanej książki jest — jak sądzę — to, że obraz i dźwięk mogą słowo przybliżać, ale też je zagłuszać, ułatwiać dzieciom spotkanie z Panem, ale też Go im zasłaniać. Ostatecznie zatem powinna być ona odczytana jako wezwanie do ostrożności i roztropności w łączeniu słowa z obrazem i dźwiękiem we mszach świętych z udziałem dzieci, abyśmy skupiając się na narzędziach, nie zapomnieli o kerygmacie.

Autorom tekstów i redaktorom monografii należy się uznanie za zachowanie jednolitości terminologicznej, co nie jest łatwe w publikacjach interdyscyplinarnych. A jeśli już mowa o interdyscyplinarności, to szkoda, że w żadnym z publikowanych w tej książce przedłożeń nie zauważono istnienia uprawianej już od kilku dziesięcioleci na uczelniach austriackich, niemieckich, szwajcarskich i brytyjskich, tzw. teologii dziecięcej. Nie umniejsza to jednak wartości tej tak bardzo potrzebnej w obrębie polskiej homiletyki publikacji.

ks. prof. UAM dr hab. Adam Kalbarczyk

Uniwersytet im. Adama Mickiewicza w Poznaniu, Polska 